\title{
The Vital Factors for Small and Medium Sized Sport Enterprises Start-ups
}

\author{
Seyed Morteza Azimzadeh ${ }^{1}$, Brenda Pitts ${ }^{2}$, Mohammad Ehsani $^{3} \&$ Asadollah Kordnaeij $^{3}$ \\ ${ }^{1}$ Ferdowsi University of Mashhad, Mashhad, Iran \\ ${ }^{2}$ Georgia State University, USA \\ ${ }^{3}$ Tarbait Modares University, Tehran, Iran \\ Correspondence: Seyed Morteza Azimzadeh, Ferdowsi University of Mashhad, Mashhad, Iran. E-mail: \\ mortezaazimzade@um.ac.ir
}

Received: May 3, 2012 Accepted: February 25, 2013 Online Published: April 27, 2013

doi:10.5539/ass.v9n5p243 URL: http://dx.doi.org/10.5539/ass.v9n5p243

\begin{abstract}
Nowadays, the new enterprises are recognized as the main source of job creation, innovation and development. In today's business world, new enterprises are recognized as an important source of job creation, innovation and development. Therefore, identifying influencing factors that play key roles in the start-up of Small and Medium Sized Enterprises (SMEs) is critical. Thus, the purpose of this study was to identify critical factors for starting-up Small and Medium sized Sport Enterprises (SMSEs) companies whose business is sport and developing a conceptual model that might be used by entrepreneurs in sport business. The methodology was qualitative. Interviews were conducted with 18 individuals, selected through purposive sampling, involved in sport-related SMEs. After a careful investigation of enterprise start-up models in the literature, and based on the results of experts interviews, an integrated approach was indicated as popular models were used by SMEs scholars. Then, a model was proposed in line with integration approach.The conceptual model is based on the integrative approach and shows that three important categories of factors were indicated: Individual; 2.individual factors; Environmental; and 3.environmental factors; and Financial factors.financial factors. It should be mentioned that these factors were constitude of subdimentiones.
\end{abstract}

Keywords: entrepreneurship, small and medium size enterprises, enterprise, start-up, sport company start-ups, vital factors

\section{Introduction}

Today, as well as throughout history, creativity and innovation are important components of a country's progress and economic growth. Thus, governments work and provide incentives to strengthen the entrepreneurial spirit. Additionally, it is acknowledged that entrepreneurship is the new economic driving force in the world and in the future will be creating thousands of new enterprises (Tonge, 2001a). Moreover, it should be pointed out that a wave of new enterprises started in the 1980s and were accompanied with lowered taxes and benefitted from the technology boom (Hormozi, 2004). At the time, the re-emergence of small and medium firms in the 1980s, particularly in terms of job creation, were in the spotlight. It makes sense, then, that a renewed emphasis on entrepreneurial growth in the business world would be greatly beneficial to the world economy. Thus, this paper seeks to review the influencing factors associated with successful start-up enterprises, and how those factors may be beneficial to sport related enterprises. Further, with an interview process with key professionals, this study sought to identify key factors for sport- related enterprises.

\section{Small and Medium Sized Enterprises (SMEs)}

There is no clear-cut and acceptable definition of small and medium sized enterprises (Storey, 1994). However, according to the Statistical Center of Iran, enterprises are classified into four groups: enterprises with 1-9 workers; enterprises with 10-49 workers; enterprises with 50-99 workers; and enterprises more than 100 workers. The Statistical Center of Iran considers only enterprises with a workforce of less than 50 as small and medium enterprises (Statistical Yearbook, 2008). 


\section{The Importance of Small and Medium Enterprises}

Studies have shown that small enterprises have accounted for as much as large enterprises for the entire world economy, thus rendering them as nearly equal importance. They have high participation and partnership with the private sector (Storey, 1994). Whereas more than 95 percent of firms in Europe are classified as SMEs, 99 percent of all enterprises in England are related to SMEs making up a total of 65 percent of total employment and 57 percent of GDP in that country (Tonge, 2001b). Hence, small enterprises have a vital role in the economy (Stanworth \& Gray, 1991). Therefore, identifying important factors that influence the creation and development of small and medium enterprises before starting up an enterprise will provide a good understanding and help initiators and entrepreneurs to be more successful. In addition, the information can be used by entrepreneurs starting sport businesses or enterprises. Therefore, research to identify and analyze the factors that influence the success of SMEs is an important step for sport entrepreneurs and founders of these companies.

\section{Theories and Models Related to Entrepreneurship and Small and Medium Enterprises}

Various theories have been proposed in relation to successful entrepreneurship and enterprise creation. Some scholars with a humanistic school of thought have referred to this as the entrepreneurial approach. This school of thought regards successful entrepreneurs as having the following characteristics: need to succeed, require low control, high need for independence and autonomy, moderate risk, high self-esteem and ability to withstand high purpose, persistence, enterprise information and preparation to deal with failure (Ostadzadeh, 2003). In line with this philosophy, there are theories of entrepreneurial personality that state an entrepreneur has many of the same characteristics as the human personality. In line with this, sociological theory considers the importance of sociological structures such as social class, family composition, social background, and parental occupation, can also be considered from a human perspective. Thus, it can be argued that these theories all see the significance of the entrepreneur as an important factor in the development of entrepreneurial activities and enterprise.

\subsection{Models and Studies Focused on Entrepreneurs}

Much research has been conducted about entrepreneurial people, leading to models that outline and describe characteristics seemingly held by most entrepreneurs. The following presents and describes a review of this research.

\subsubsection{Entrepreneurial Skills}

Some research has reported specific factors labeled as 'entrepreneurial skills'. Entrepreneurs are people who have the knowledge and skills to gain entrance into other enterprises, markets, products or new technologies. On the other hand, lack of entrepreneurial skills is a major challenge faced by entrepreneurs in establishing enterprises and the major reason for poor performance in the company. If lack of these skills and areas of their enterprise and costs are minimized, then the chances of a new enterprise venture will be at the maximum (Papagiannidis \& Li, 2005). In this regard, Chen, Green, \& Crick (1998), offered the following skill areas for entrepreneurs: marketing; management; risk; and financial control. Anderson, Pyysiainen, Mcelwoo, and Vesala (2006) classified the entrepreneurship skills as following: (1.) Individual skills, such as: innovation, risk ability, ability to deal with unknowns, accept challenges, responsibility and search for change opportunities; (2.) Communication skills, such as: effective interaction with others, effective communication, negotiation (bargaining, and effective leadership; and, (3.) Process skills, such as: program planning and organization ability, analysis ability, environment analysis and evaluation, and plans implementation ability.

\subsubsection{Personality Characteristics}

Researchers have paid attention to the characteristics of individuals as one of the factors at stake in creating new enterprises (Schwarz, Wdowiak, Almer-Jarz \& Breitenecker, 2009) and expressed that more than 20 percent variance of entrepreneurial intention can be explained through personality characteristics (Frank, Lueger, \& Korunka, 2007). Thus, research has shown the personality characteristics for entrepreneurial intention are: the need for success, the amount of risk taking, creativity and self-control (Brockhaus \& Horwitz, 1986, quoted by Schwarz et al., 2009). In another study, the results of Frank et al. (2007), have also confirmed this finding. However, much research has been carried out involving the important position and influential personality characteristics noted in the creation of small and medium enterprises (Acs \& Audretsch, 1989; Hall \& DeVaney, 2009; Pillis \& Reardon, 2007; Schwarz et al., 2009) but the other researchers also viewed it with skepticism including Kessler (2007) and Masodnia (2007), pointing out that personality paradigms in entrepreneurship face serious issues and challenges. They also acknowledged that in general, personality characteristics are meaningful only in relation to other factors such as environment, founder resources and processes. 


\subsubsection{Background Factors}

The personality approach to entrepreneurship research can in fact reduce the number of characteristics used in describing entrepreneurs just to a single component to describe the whole aspect of entrepreneurship. In this regard, the use of other approaches, such as a demographic approach to achieve the ideal profile of an entrepreneur via demographic information seems inevitable (Masodnia, 2007). Accordingly, a large pool of research has considered the demographic variables as predictors. Shane and Venkataraman, (2000) pointed out in their study that parents and close friends or neighbors provide encouragement for someone thinking about entering the market with a new business. The findings of earlier studies (Bates, 1995) showed similar results. In research on graduates in England, Dolton and Makepeace (1990) concluded that gender, age and social class shaped the motivation for the enterprise. In another study, in the United States, it was reported that marital status, education and financial support had a significant relationship in creating enterprise and employment amongst employed and jobless workers (Evans \& Leighton, 1990).

\subsection{Environmental Factors}

Another group of researchers pointed to the environmental school of thought and a set of environmental factors, such as: good environment, economic, social, political, technological factors. According to this school of thought, without the proper environment, entrepreneurship and enterprise will not be possible. In entrepreneurship, the relationship between the environment and the organization is a newly developed approach. Supporters of this approach believe that the entrepreneurial personality approach has reached its end and has a small contribution to the understanding of the new company (Mazzarol, Volery, Doss, \& Thein, 1999). It is worth noting that the behavioral theories have a focus on environmental factors. Accordingly, environmental factors such as supportive government policies, economic conditions, education, etc. are effective in entrepreneurship and the new enterprise creation process (Ostadzadeh, 2003). The enterprise environment is analyzed with an evaluation of different models including the PEST model. PEST stands for political, economic, social and technological factors.

\subsubsection{Political Factors}

Some researchers point to the role of government in facilitating entrepreneurial activity and creating new enterprises. Some of the most important government policies and programs for development of entrepreneurship include formulation of relevant laws and regulations, tax policies, simplicity of administrative procedures, financial support and loans, promoting entrepreneurship and education, information and advice to entrepreneurs and creating the necessary infrastructure (Lundstrom \& Stevenson, 2001). In general, according to Fini, Grimandi, \& Sobrero (2009), one of the most important ways to encourage the public sector to create enterprise is providing financial packages.

\subsubsection{Economic Factors}

All enterprises are affected by national and international economic factors. Such factors are the type of economic system prevailing in the country; government interference in free markets; competitive market advantages; the change rate and monetary stability in the country; the efficiency of financial markets; quality of infrastructure; labor skills; labor costs; the rate of economic growth; unemployment rate; interest rates; and inflation (Vienna, 2006). In addition, the economic environment refers to economic indicators; economic recession; capital and unemployment (Abdul Majid, Mohd, \& Mohd, 2008).

\subsubsection{Cultural and Social Factors}

Research shows that cultural and social factors can influence the entrepreneur. This research shows that the factors that influence people's willingness and new approaches for SMEs include: lifestyle changes; cultural aspects of the macro environment; demographic factors (population growth rate distribution, age, etc.); class structure; education; culture (gender roles, etc.); entrepreneurial spirit; attitudes (health, career and job, etc.); leisure interests; social values; preferences and standards of living; and, social trends, such as, changes in the demographic profile and environmental protection (Vienna, 2006). According to Morrison (2000), there is a significant relationship between culture and entrepreneurship. In addition, GEM (2000-2002), made clear that the British social and cultural conditions (e.g., negative attitudes to create value and enterprise failure) was the main obstacles to the growth of entrepreneurship (Abdul Majid et al., 2008). Overall, the values and beliefs can shape behavior and culture of a society (Mueller \& Thomas, 2000). Accordingly, many studies are associated with the relationship between culture and entrepreneurship (Lee \& Peterson, 2000; Mueller \& Thomas, 2000).

\subsubsection{Technological Factors}

Technological progress has been shown to influence and/or create opportunities for an entrepreneurial 
environment. For example, production of mobile technology is an achievement, but the motivation behind it is a growing population that will be willing to communicate with their colleagues, customers, friends and their families in any place and time. Additionally, the technology of many websites makes it possible for customers to order goods through the Internet. It should be noted that this impact is not just that the technology itself is so attractive. Rather, the main reason that people buy online is because more people are busy and prefer to shop whenever they have time to buy (Baringer \& Ireland, 2009). The technology provides the opportunity, and entrepreneurs created the technology for the opportunity.

\subsection{Capital Factors}

Capital refers to funds available for investment. Because the theory of entrepreneurship partially emphasizes capital and wealth creation (Ostadzadeh, 2003), this is a factor whenever the risk of investment in time and place occurs. Achieving the required funds for enterprises has always been a challenge for entrepreneurs. Successful entrepreneurs have the skills needed to obtain funds from a variety of ways. Certainly, to participate in the economy, SMEs are required to optimize the organization and strengthen the competitive vigor (Amid and Ghamkhari, 2009).

\subsubsection{Financing Small and Medium Sized Enterprises}

A wide range of funding is available to entrepreneurs. Different ways of classifying them are proposed in the literature. In one study, Deakins and Freel (2003) classified financial resources of entrepreneurial companies into two categories: external and internal parts. In another categorization, Cardlo (1999), divided the financial resources into two categories: formal and informal sources (quoted by Sadrynia, Mirasadi, \& Varvani, 2009); while Sadrynia et al. (2009) and Eslami and Bigdlo (2005) divided funding for small and medium enterprises into four categories: 1. private sources of financing; 2. debt financing (borrowing); 3. financing the capital (equity); and 4. internal financing.

Private sources of finance; Private sources are the first sources of funds needed to provide entrepreneurs and start-up enterprise to make it work. These resources typically include: 37 private sources (personal savings), and friends and relatives. Debt financing (borrowing) to finance through debt involves borrowing funds that owners of SMEs have to repay with interest. These sources include funds from commercial banks as short-term, medium-term and long-term loans. Enterprise owners regard banks as lenders followed by financial institutions credit and insurance companies. Equity financing; In this method, while the risks are shared, the potential revenues will be divided. Some common sources of equity financing are enterprise angels: these are wealthy individuals who invest directly in companies that are in the beginning and have not yet determined a price for them. They have no relationship with the entrepreneur (Deakins and Freel, 2003). Internal financing; consists of both outside funding and internal sources. But in turn, an enterprise has the capacity to generate capital. This type of financing is available for small companies.

It should be noted, financial resources are necessary to create a enterprise entity (Kessler and Frank, 2009) and enterprise capital double with environmental and individual factors. Thus, researchers have shown that financial capital is the resources required for the formation of new institutions and activities, and financial decisions (Cassar, 2004). In this connection, researchers such as Abdul Majid et al. (2008) showed that most respondents (77 percent) expressed a lack of capital for start-up, while $66 \%$ did not know fundraising methods. Findings like these underpin the importance of awareness of the diversity of funding sources and how they can help entrepreneurs in SMEs achieve success.

\section{Comprehensive Models for Small and Medium Enterprises}

As mentioned earlier, each of the theories and schools considered entrepreneurship and creating new enterprise processes from their unique perspectives. So to address the weaknesses and strengths of these approaches, researchers developed a theory known as integrated theory. This approach is a combination of afore-mentioned theories and puts forth the argument that each approach cannot alone provide entrepreneurship and enterprise. The integrated theory considers all previous theories such as specifications and features inherent in the theory of the entrepreneurs, events for entrepreneurs, potential investors and wealth creation (economic theory), as well as sociological structures (Ostadzadeh, 2003). Under this approach, much research and discussion explained the entrepreneurship and small and medium enterprises processes. These models are presented in the following.

In his conceptual model to describe the phenomenon of creating a new enterprise venture, Gartner (1985) suggested the following combination of factors: (1) people: persons who involved in starting a new enterprise; (2) organization: the type of company which is created; (3) environment: the new organization situation; and, (4) process: activities that are performed by individuals for the enterprise. 
Greenberger and Sexton (1988) reported that a start-up enterprise probably arises from the interaction of several factors including: personality, situational variables (social exclusion, environmental protection, financial and family support), and perceptions of social support. However, the Acs and Audretsch (1989) study showed that a small company start-up is a decision that is taken by a person in the employment market and is a decision influenced by several factors, such as work experience, motivation, personality, norms and social conditions, family environment. In another study of SMEs reported by Mazzraol et al. (1999), factors that influenced the creation of small enterprises were investigated. Conclusions drawn were that personal and environmental factors are the main factors.

In relation to environmental factors, Specht (1993) acknowledged that environmental factors affecting a enterprise organization are social economic, political and infrastructure factors. McPhee (2000) also refereed to individual and environmental factors. He offered the following factors in his model of entrepreneurial behavior: (1) the underlying economic-social including sex, age, social class, educational status, marital status and race; (2) conditional factors including social- economic structure, economic and regional development; (3) individual factors including the need for achievement, internal control, the need for independence, creative behavior and social psychology; and (4) macroeconomic factors including political shifting, cultural displacement, economic dislocation, capital inquest, and environmental factors.

Other scholars, such as Parker and Belghitar (2006), expressed that individual characteristics and economic success are doubled with enterprise venture. Some others mentioned factors for success. For example, Reynolds (2007) offered primary factors needed for success in an enterprise start-up: enterprise experience, financial structure and activities for organization, a team for financial commitment, aggregate resources, and rapid creation activities. Van Vuuren and Groenewald (2007) also offered successful factors in an enterprise: interpersonal conflict at work, role models, effective time management, and support for parents and counselors. Of considerable research in this area is that of Smith (2008) who considered these factors needed for success: financial factors, individual factors, economic factors, and government factors.

Fini et al. (2009) also explored factors in the development of enterprise in universities and pointed to three factors: macro-level determinants (environmental impact); mechanisms to support university-level determinants; and micro-level factors (factors related to individual level). It can be seen that once again the importance of environmental and individual factors in an enterprise is noted. Schwarz et al. (2009) showed in their model that a combination of environmental and individual factors is related to entrepreneurial intention. That proposed model focused on three components: public attitudes, entrepreneurial attitudes and perceptions of environmental conditions. Hall and DeVaney (2009), in their study, come to the conclusion that factors such as attitude, subjective norm (gender, race, and parents) and perceived behavioral control (education and training and experience) affected the enterprise. Also, Townsend, Busenitz, \& Arthurs (2010), in their study, expressed great confidence that the people decided to launch their enterprise even with the high probability of failure of their enterprises.

As mentioned earlier, researchers developed combined or interactive models to explain the factors affecting small and medium enterprises. These models are summarized to facilitate the study process (see Table 1). It should be noted that most research in the field of entrepreneurship appears to fall into two broad categories: the entrepreneur's personal characteristics or features; and underlying factors (environment) such as economic, social, cultural and political.

\section{Purpose of Study}

In today's business world, new enterprises are recognized as an important source of job creation, innovation and development. Therefore, identifying influencing factors that play key roles in the start-up of small and medium sized sport enterprises (SMSEs) is critical. Thus, the purpose of this study was to identify critical factors for SMEs start-up companies whose business is sport.

\section{Research Methodology}

Previous research reveals a number of factors that influence the creation of small and medium businesses. Using interview methodology, we attempted to identify those factors associated with SMSEs. Toward this, 18 active researchers in the field of entrepreneurship and SMEs were selected through purposive sampling and were arranged for semi-structured interviews. It should be noted that the findings reached the saturation point in the samples of 14, 15, 16, 17 and 18. Table 2 provides the demographics of the interviewees. Most respondents (67\%) were aged between 30 and 50 years and most of them (72\%) had a Ph.D. and were university professors. 
Table 1. Summary of some research on influencing factors SMEs

\begin{tabular}{|c|c|c|}
\hline Scholar(s) & Title & Influential Factors Listed \\
\hline Gartner (1985) & $\begin{array}{l}\text { Conceptual framework for describing } \\
\text { the phenomenal of new venture creation }\end{array}$ & People, environment, organization, process \\
\hline $\begin{array}{l}\text { Acs and Audretsch } \\
\text { (1989) }\end{array}$ & Births and firm size & $\begin{array}{l}\text { Work experience, motivation, personality, norms and } \\
\text { social conditions, family environment. }\end{array}$ \\
\hline $\begin{array}{l}\text { Mazzarol et al. } \\
(1999)\end{array}$ & $\begin{array}{l}\text { Factors influencing small business } \\
\text { start-ups: A comparison with previous } \\
\text { research }\end{array}$ & $\begin{array}{l}\text { Individual characteristics; individual background and } \\
\text { environmental factors }\end{array}$ \\
\hline Shook et al. (2003) & $\begin{array}{l}\text { Venture creation and the enterprising } \\
\text { individual: A review and synthesis }\end{array}$ & Psychological characteristics, traits, characteristics, \\
\hline Cassar (2004) & The financing of business start-ups & $\begin{array}{l}\text { Loans, long-term loans, external investment and } \\
\text { investment banking. }\end{array}$ \\
\hline $\begin{array}{l}\text { Montgomery, } \\
\text { Johnson, and Faisal } \\
(2005)\end{array}$ & $\begin{array}{l}\text { What kind of capital do you need to start } \\
\text { a business: financial or human? }\end{array}$ & $\begin{array}{l}\text { Significant positive impact on individual investors and } \\
\text { financial capital but human capital is more important to } \\
\text { enterprise }\end{array}$ \\
\hline $\begin{array}{l}\text { Parker and Belghitar } \\
(2006)\end{array}$ & 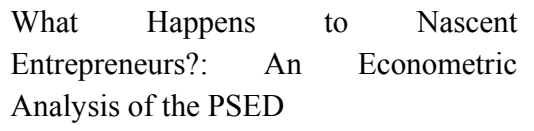 & Individual and economic characteristics \\
\hline $\begin{array}{l}\text { Van Vuuren and } \\
\text { Groenewald (2007) }\end{array}$ & $\begin{array}{l}\text { A Critical Analysis of the Influence of } \\
\text { Start-Up Factors in Small Businesses } \\
\text { and Entrepreneurial Ventures in South } \\
\text { Africa }\end{array}$ & $\begin{array}{l}\text { Interpersonal and conflict management, role models, } \\
\text { effective time management, and parent support advisers }\end{array}$ \\
\hline Smith (2008) & $\begin{array}{l}\text { A statistical analysis of the impact of the } \\
\text { enterprise act } 2002 \text { on business start-ups } \\
\text { in England and Wales }\end{array}$ & Financial, personal, economic, governmental \\
\hline Fini et al. (2009) & $\begin{array}{l}\text { Factors fostering academics to start up } \\
\text { new ventures: an assessment of Italian } \\
\text { founders' incentives }\end{array}$ & $\begin{array}{l}\text { Macro-level determinants (environmental impact); } \\
\text { mechanisms to support university-level and micro level } \\
\text { factors (individual-level factors) }\end{array}$ \\
\hline $\begin{array}{l}\text { Hall and DeVaney } \\
(2009)\end{array}$ & $\begin{array}{l}\text { Job Generation and New and Small } \\
\text { Firms: Some Evidence from the Late } \\
\text { 1980s }\end{array}$ & $\begin{array}{l}\text { Attitude, subjective norms, perceived behavioral control, } \\
\text { intention to treat }\end{array}$ \\
\hline $\begin{array}{l}\text { Hossain, Naser, } \\
\text { Zaman, \& Nuseibeh } \\
(2009)\end{array}$ & $\begin{array}{l}\text { Factors influencing women business } \\
\text { development in the developing countries } \\
\text { Evidence from Bangladesh }\end{array}$ & $\begin{array}{l}\text { Desire for financial independence and decision making, } \\
\text { network and market information, availability of capital } \\
\text { and the main component of the knowledge and skills in } \\
\text { their employees were women. }\end{array}$ \\
\hline Schwarz et al. (2009) & $\begin{array}{l}\text { The effects of attitudes and perceived } \\
\text { environment conditions on students' } \\
\text { entrepreneurial intent An Austrian } \\
\text { perspective }\end{array}$ & $\begin{array}{l}\text { Public attitudes, perceptions and understanding of the } \\
\text { entrepreneurial environment. }\end{array}$ \\
\hline
\end{tabular}

Table 2. Descriptive demographics of respondents (Interviewees)

\begin{tabular}{lcccccccccccc}
\hline Variable & \multicolumn{2}{c}{ Gender } & \multicolumn{4}{c}{ Age } & \multicolumn{3}{c}{ Education } \\
& female & male & $30-40$ & $41-50$ & $51-60$ & $61-70$ & MA & Ph.D.candidates & Ph.D. & Student & Researcher & Professor \\
\hline $\begin{array}{l}\text { Total } \\
\text { Total }\end{array}$ & 4 & 14 & 5 & 7 & 4 & 2 & 3 & 2 & 13 & 2 \\
\hline
\end{tabular}

\section{Findings}

Analysis of the interviews with the experts suggested that individual factors (entrepreneurial personality, background, life experience and skills needed in the field of entrepreneurship) and the environmental factors 
interact with each other as the main factors involved in creating businesses which were consistent with the results of the research literature. Interestingly, samples considered the individual factors more important than environmental factors. Additionally, they deemed initial capital as a main factor in SMEs establishment. They also expressed that the entrepreneur's personal assets were more important than bank loans in terms of SMEs creation.

\section{Discussion and Conceptual Model}

This study aimed to explore the most influencing factors in an entrepreneurial business creation. A review of literature identified three main schools of thought in regard to entrepreneurship and SMEs. First, a humanistic school of thought focuses on the entrepreneurs and their personal respective concerns. Accordingly, the entrepreneur's personalities and backgrounds including family, education, work experience and entrepreneurship, gender, age etc., play decisive roles in creating successful new businesses (Acs \& Audretsch, 1989; Frank et al., 2007; Hall \& DeVaney, 2009; Pillis \& Reardon, 2007; Shook, Priem, \& McGee, 2003; Van Gelderen, Thurik, \& Bosma, 2006; Van Vuuren \& Groenewald, 2007).

Second, the environmental factors were forwarded as influencing factors, referring to macro-environmental factors, such as politics, economics, society-culture and technology in creating an effective business (Specht, 1993; Vienna, 2006).

A third approach was found - the interactive approach. In this approach, the model shows entrepreneurs try to establish a mix of individual and environment factors to be successful. It should be noted most researchers thought the approaches should interact together to achieve success in creating SMEs (Fini et al, 2009; Gartner, 1985; Abdul Majid et al., 2008; Korunka, Frank, Lueger, \& Carsrud, 2003; Mazzraol et al., 1999; Parker and Belghitar, 2006; Schwarz et al., 2009; Smith, 2008). Also, the experts interviewed in this study agreed on this issue and acknowledged that In order to be successful in the SMEs creation process, two factors should be considered together in a noted interactive approach.

Others believed in resources dimension as a success factor for SMEs (Parker \& Belghitar, 2006; Van Gelderen et al., 2006). Some others established the pull and push factors of the environment for success in creating SMEs (Liao \& Gartner, 2006; Parker \& Belghitar, 2006). Other researchers said the results of operations and processes were important in this regard (Liao \& Gartner, 2006; Parker \& Belghitar, 2006; Van Gelderen et al., 2006). But what is certain is that the environmental factors (including political, economic, social and technological), individual factors (which were referred to the entrepreneur's personality and background) and resources (human and financial capital) were manifest in the majority of findings believed as factors interact with each other towards entrepreneurship and SMEs.

Perhaps one of the important reasons regarding the interactive approach is that researchers are capable of including other factors into their models by using it. Hence, according to the literature review and the expert panel opinions revealed in the interviews, the financial and capital resources, also, can be very necessary and one of the most important factors in SMEs (Kessler \& Frank, 2009). So this factor was doubled with individual and environmental factors and was included into the conceptual model.

\section{A Proposed Conceptual Model for SMSEs}

According to the literature and interactive model, it can be concluded that, in general, the majority of research on factors affecting the business, environmental factors and individual factors have been considered as important and influential and play a central role in the process of creating business (Mazzarol et al., 1999). However, a number of researchers have attempted to ensure that each of these factors contributed effectively to the creation of small and medium enterprises, but it should also be kept in mind that these factors can contribute to business creation if considered together. Of course, we can include other important facilitating factors (e.g. resources and financial capital) in terms of the creation of new small and medium businesses in the interactive model (Kessler and Frank, 2009). Hence, this factor has been studied in this conceptual model, as well. Accordingly, the conceptual model and its theoretical basis are described here.

Each of the reviewed theories and schools of thought considered entrepreneurship and new business processes from their own perspective. So to cover the weaknesses of these approaches and take advantage of their strengths, researchers suggested another theory known as the comprehensive retrospective. This integrated approach is based on the belief that each approach, alone, cannot fully investigate the entrepreneurial and business aspects. Therefore, the underlying theory and the proposed conceptual model encompasses all factors in creating a business and entrepreneurial process such as common specifications and features inherent in the entrepreneurs, their business and life events, environmental factors, investment and wealth creation potential (economic theory) 
and sociological structures (Ostadzadeh, 2003).

Our proposed conceptual model for SMSEs involves an integrative approach wherein the entrepreneur, the environment (including: political, economic, Sociocultural, technical) and financial are equally important influencing factors. Accordingly, with respect to existing models in the creation of small and medium businesses and considering the important factors in this process, we developed the conceptual model shown in Figure 1.

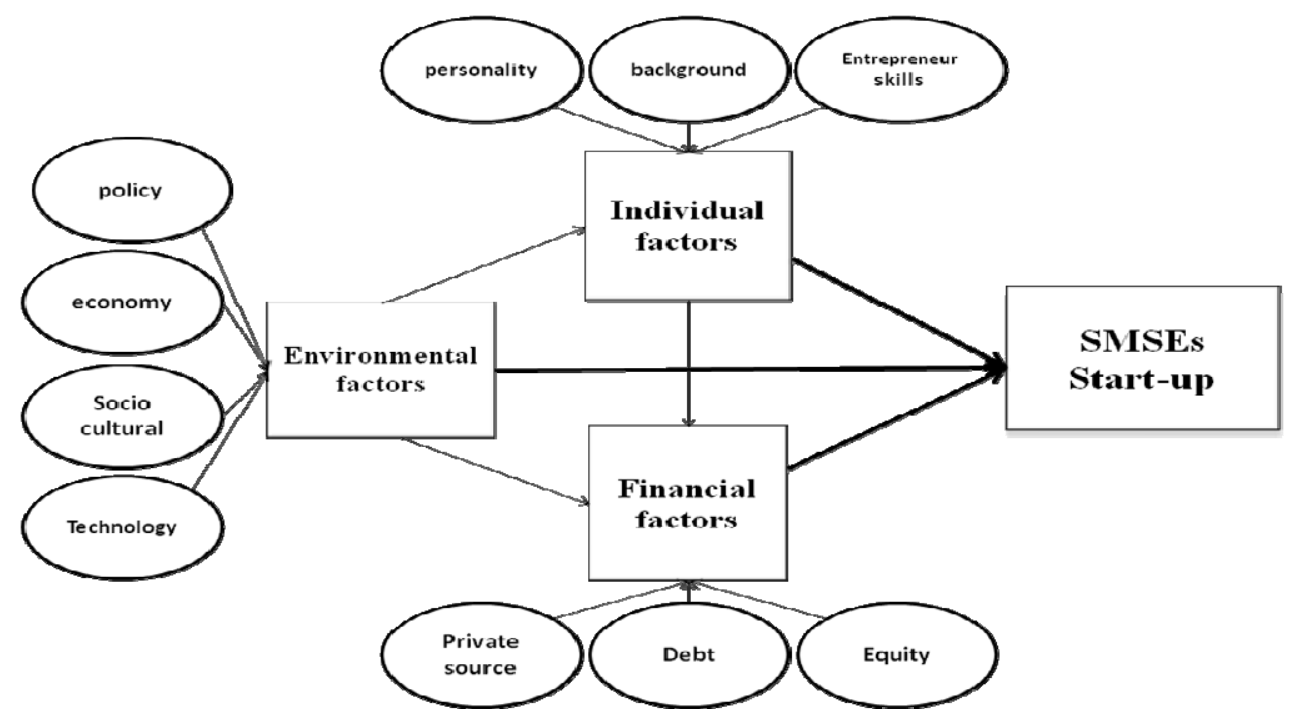

Figure 1. A proposed conceptual model for SMSEs start-up

As can be seen in the model, three main factors are important to small and medium businesses start-up, including: environmental, individual and financial factors. Each of these primary factors has sub-categories of factors, as shown. The environmental factor consists of sub-factors such as political, sociocultural, economic, and technology dimensions. The individual factors consists of personality characteristics of entrepreneurs, entrepreneurial skills and the individual's background dimensions. The financial factor includes private resources, capital and equity and debt subdivisions. Presumably, these factors may interact with each other for a proper analysis of business processes and possibly cover the weaknesses and take advantage of the strengths of previous models to develop a more comprehensive model in order to effectively consider the SMEs start-up. It seems that, compared to other models, this model can display the most critical factors influencing business start-up specially for small and medium sized sport enterprises.

\section{Future Research Considerations}

As we have presented a conceptual model for SMSEs, a next step in this line of research is to test this model. Future studies could involve the application of this model to sport business SMEs that recently started to examine whether or not the entrepreneurs and their processes utilized any, some, or all of the factors presented in the conceptual model. Another study might involve identifying entrepreneurs who are considering starting a sport business enterprise and offer this model for their use; then examine the outcome to determine if this model is practical.

\section{References}

Abdul Majid, I., Taib Dora, M., \& Fauzi Kamarudin, M. (2008). Factors influencing the formation of business ventures. Journal of Human Capital Development, 1(1), 29-40.

Acs, Z., \& Audretsch, D. (1989). Births and firm size. Southern Economic Journal, (55), 467-475. http://dx.doi.org/10.2307/1059223

Aldrich, H., \& Zimmer, C. (1986). Entrepreneurship through social networks . In H. Aldrich (Ed.), Population Perspectives on Organizations, Acta Universitatis Upsaliensis (pp. 13-28). Uppsala.

Aldrich, R., Aldrich, H., \& James, M. (2000). Family matters: gender, networks, and entrepreneurial outcomes. Social Forces, 79(2), 523-546.

Amid, A., \& Ghamkhari, M. (2009). The study of information technology on developing of small and medium sized industry export in Iran. Cheshmandaz Modiriat, 32, 183-202. 
Anderson, A., Pyysiainen, J., Mcelwoo, G., \& Vesala, K. (2006). Developing the entrepreneurial skills of farmers. International Journal of Entrepreneurial Behavior \& Research, 12(1), 24.

Baringer, B. R., \& Ireland, R. D. (2009). Entrepreneurship: Successfully launching new ventures. (Translated in Persian by: Moghadam, G., Moameni, N., \& Moameni, N., Saffar, 1st ed.). Tehran, Iran.

Bates, T. (1995). Self-employment entry across industry groups. Journal of Business Venturing, 10, 143-156. http://dx.doi.org/10.1016/0883-9026(94)00018-P

Cassar, G. (2004). The financing of business start-ups. Journal of Business Venturing, (19), 261-283. http://dx.doi.org/10.1016/S0883-9026(03)00029-6

Chen, C., Greene, P., \& Crick, A. (1998). Does entrepreneurial self-efficacy distinguish entrepreneurs from managers? Journal of Business Venturing, 13(4), 295-316. http://dx.doi.org/10.1016/S0883-9026(97)00029-3

Deakins, D., \& Freel, M. (2003). Entrepreneurship and small firms (3rd ed.). Berkshire: Mc Grow Hil.

Dolton, P., \& Makepeace, C. (1990). Self-employment among graduates. Bulletin of Economic Research, 42(1), 35-53. http://dx.doi.org/10.1111/j.1467-8586.1990.tb00290.x

Eslami, G. H., \& Bigdlo, M. (2005). Investigation influencing criteria on evaluation of entrepreneurial business. Danesh Modiryat, 68, 3-29.

Evans, D., \& Leighton, L. (1990). Small business formation by unemployed and employed workers. Small Business Economics, 2(4), 319-330. http://dx.doi.org/10.1007/BF00401628

Fini, R., Grimaldi, R., \& Sobrero, M. (2009). Factors fostering academics to start up new ventures: an assessment of Italian founders' incentives. $J$ Technol Transf, (34), 380-402. http://dx.doi.org/10.1007/s10961-008-9093-z

Frank, H., Lueger, M., \& C, K. (2007). The significance of personality in business start-up intentions, start-up realization and business success. Entrepreneurship \& Regional Development, (19), 227-251. http://dx.doi.org/10.1080/08985620701218387

Gartner, W. (1985). Conceptual framework for describing the phenomenal of new venture creation. Academy of Management Review, 10(4), 696-706.

Greenberger, B. D., \& Sexton, D. L. (1988). An interactive model of new venture initiation. Journal of Small Business Management, 26(3), 1.

Hall, A., \& DeVaney, S. (2009). Factors that influence small business start-up. The 55th Annual Conference of the American Council on Consumer Interests, July 26-28. Milwaukee, Wisconsin.

Hormozi, A. (2004). Becoming an entrepreneur: How to start a small business. International Journal of Management, 21(3), 278-285.

Hossain, A., Naser, K., Zaman, A., \& Nuseibeh, R. (2009). Factors influencing women business development in the developing countries Evidence from Bangladesh. International Journal of Organizational Analysis, 17(3), 202-224. http://dx.doi.org/10.1108/19348830910974923

Kessler, A. (2007). Success factors for new businesses in Austria and the Czech Republic. Entrepreneurship \& Regional Development, 19, 381-403. http://dx.doi.org/10.1080/08985620701439959

Kessler, A., \& Frank, H. (2009). Nascent entrepreneurship in a longitudinal perspective : The impact of person, environment, resources and the founding process on the decision to start business activities. International Small Business Journal, 27(6), 720-742. http://dx.doi.org/10.1177/0266242609344363

Korunka, C., Frank, H., Lueger, M., \& Carsrud, A. (2003). The entrepreneurial personality in the context of resources, environment and the startup process - a configurationally approach. Entrepreneurship: Theory \& Practice, 28(1), 411-432. http://dx.doi.org/10.1111/1540-8520.00030

Lee, D., \& Tsang, E. (2001). The effects of entrepreneurial personality. Background and network activities on venture growth. Journal of Management Studies, 38(4), 583-602. http://dx.doi.org/10.1111/1467-6486.00250

Liao, J., \& Gartner, W. B. (2006). The effects of pre-venture plan timing and perceived environmental uncertainty on the persistence of emerging firms. Small Business Economics, 27(1), 23-40. http://dx.doi.org/10.1007/s11187-006-0020-0 
Lundstrom, A., \& Stevenson, L. (2001). Entrepreneurship policy for the future, Vol1 of the Entrepreneurship for the Future Series. Swedish Foundation for Small Business Research, 133-156.

Masodnia, E. (2007). Investigation the reliability of personality's dimensions and predicting entrepreneurship. Daneshvar-e-Raphtar, 14(23), 53-64.

Mazzarol, T., Volery, T., Doss, N., \& Thein, V. (1999). Factors influencing small business start-ups: A comparison with previous research. International Journal of Entrepreneurial Behavior \& Research, 5(2), 48-63. http://dx.doi.org/10.1108/13552559910274499

McPhee, I. (2000). Towards an understanding of business start-ups through diagnostic finger printing. Management Research Centre. University of Wolverhampton, UK.

Montgomery, M., Johnson, T., \& Faisal, S. (2005). What kind of capital do you need to start a business: financial or human? The Quarterly Review of Economics and Finance, 45, 103-122. http://dx.doi.org/10.1016/j.qref.2003.11.005

Morrison, A. (2000). Initiating entrepreneurship. In S. Carter, \& D. Jones-Evans (Eds.), Enterprise and Small Business: Principles, Practice and Policy, Financial Times. London: Prentice-Hall.

Mueller, S. L., \& Thomas, A. S. (2000). Culture and entrepreneurial potential: A nine country study of locus of control and innovativeness. Journal of Business Venturing, 16, 51-75. http://dx.doi.org/10.1016/S0883-9026(99)00039-7

Ostadzadeh, Z. (2003). Entrepreneurship, development and occupation. Rahyapht, 29, 71-81.

Papagiannidis, S., \& Li, F. (2005). Skills brokerage: A new model for business start-ups in the networked economy. European Management Journal, 23(4), 471-482. http://dx.doi.org/10.1016/j.emj.2005.06.002

Parker, S. C., \& Belghitar, Y. (2006). What hppens to nscent etrepreneurs? An eonometric aalysis of the PSED. Small Business Economics, 27(1), 81-101. http://dx.doi.org/10.1007/s11187-006-9003-4

Pillis, E. D., \& Reardon, K. K. (2007). The influence of personality traits and persuasive messages on entrepreneurial intention A cross-cultural comparison. Career Development International, 12(4), 382-396. http://dx.doi.org/10.1108/13620430710756762

Reynolds, P. D. (2007). New firm creation in the United States: A PSED I Overview. Foundations and Trends in Entrepreneurship, 3(1).

Sadrynia, M., Mirasadi, S., \& Varvani, M. (2009). Different ways to small and medium sized financial provision on different stages of life cycle. Roshd Fanavari, 19, 13-21.

Schwarz, E. J., Wdowiak, M. A., Almer-Jarz, D. A., \& Breitenecker, R. (2009). The effects of attitudes and perceived environment conditions on students' entrepreneurial intent An Austrian perspective. Education + Training, 51(4), 272-291. http://dx.doi.org/10.1108/00400910910964566

Shane, S., \& Venkataraman, S. (2000). The promise of entrepreneurship as a field of research. Academy of Management Review, 25(1), 217-226.

Shook, C. L., Priem, R. L., \& McGee, J. E. (2003). Venture creation and the enterprising individual: A review and synthesis. Journal of Management, 29(3), 379-399.

Smith, P. (2008). A statistical analysis of the impact of the enterprise act 2002 on business start-ups in England and Wales. Department for business enterprise and regulatory reform 2008.

Specht, P. (1993). Munificence and carrying capacity of the environment and organization formation. Entrepreneurship Theory and Practice, 17(2), 77-86.

Stanworth, J., \& Gray, C. (1991). Bolton 20 years on: the small firm in the 1990s. London: Paul Chapman.

Storey, D. (1994). Understanding the small business sector. London: International Thomson Business Press.

Tonge, J. (2001a). A review of small business literature part 1: defining the small business. Manchester Metropolitan University Business School Working Paper Series. Retrieved from http://www.ribm.mmu.ac.uk/wps/papers/01-18.pdf

Tonge, J. (2001b). A review of small business literature part 2: birth, growth and death of the small business. Manchester Metropolitan University Business School Working Paper Series. Retrieved from http://www.ribm.mmu.ac.uk/wps/papers/01-19.pdf

Townsend, D. M., Busenitz, W. L., \& Arthurs, D. J. (2010). To start or not to start: Outcome and ability 
expectations in the decision to start a new venture. Journal of Business Venturing, 25, $192-202$. http://dx.doi.org/10.1016/j.jbusvent.2008.05.003

Van Gelderen, M., Thurik, R., \& Bosma, N. (2006). Success and risk factors in the pre- startup phase. Small Business Economics, 26(4), 319-335. http://dx.doi.org/10.1007/s11187-004-6837-5

Van Vuuren, J., \& Groenewald, D. (2007). A critical analysis of the influence of start-up factors in small businesses and entrepreneurial ventures in South Africa. Acta Commercii, 269-280. Retrieved from http://hdl.handle.net/2263/4288

Vienna, L. X. (2006). A comparative study on the business environment in Huizhou and Heyuan of the Guangdong Province. Master of Arts in China Development Studies, The University of Hong Kong. 